\title{
INTRODUCING DESIGN IN FIRST YEAR CHEMICAL ENGINEERING AT UNIVERSITY OF WATERLOO
}

\author{
Christine Moresoli and Michael W. Fowler \\ Department of Chemical Engineering, University of Waterloo, Ontario Canada \\ cmoresol@uwaterloo.ca
}

\section{INTRODUCTION}

A clear grasp of 'Design Methodology' is an important and essential element of the engineering profession. In the Chemical Engineering curriculum, teaching design methodology is generally included in the curriculum through the completion of a 'capstone design project' offered in the last year. Other key technical elements of chemical engineering design skills are integrated into the curriculum, typically in upper year chemical engineering core courses (e.g. chemical reactor design, separations, heat transfer). The design elements in these core courses are not as distinct as the capstone design project as they are intimately related to the fundamental concepts introduced in the course, and provide the students with specific technical skills to undertake design in the chemical engineering sector. To date in most first year chemical engineering concepts courses, design components are only presented as the most rudimentary form as 'heat and mass balance', but 'design methodology' itself is often not presented.

At Waterloo it was felt that the first year chemical engineering concepts course represented an appropriate platform to introduce, in a structured approach, elements of the design process. The learning objectives of this initiative were to (1) expose students to open ended problems; (2) how to source information; and (3) allow them to develop their technical communication skills.

\section{METHODS}

A three step approach, illustrated in Table 1, was developed to expose first year chemical engineering students to the design methodology.

Table 1: Approach for the teaching of design in first year chemical engineering concepts course

\begin{tabular}{|l|l|}
\hline Step & Description \\
\hline Step 1 & $\begin{array}{l}\text { Introduction to Design Methodology - formal lecture style } \\
\text { presentation }\end{array}$ \\
\hline Step 2 & $\begin{array}{l}\text { Structured engineering design case study assignment- } \\
\text { based on an Engineering Without Borders (EWB) rain } \\
\text { collection problem statement }\end{array}$ \\
\hline Step 3 & Conceptual Design Case Study assignment \\
\hline
\end{tabular}

The structured engineering case study, Step 2, was given as an assignment with a clear problem statement, the design of a roof rainwater harvesting storage system. In this assignment, the use of Excel to conduct simple modeling analysis was also taught and practiced. This problem was developed by the office of 'Waterloo Cases in Design Engineering (WCDE)' and adapted to suit the needs of the first year Chemical Engineering course. In using a structured design methodology approach, students were asked to answer the following; (1) need analysis; (2) conceptual design; (3) preliminary design; (4) detailed design (where an Excel simulation was used to determine reliable of water availability in the tank based on rainfall data, as well a roof design and tank size); (5) implementation; (6) operation; and (7) retirement.

The 'Conceptual Design Case Study' assignment, Step 3, was an open-ended case study to develop the student's basic literature review and analysis skills while reinforcing the early steps of design methodology. The students had to select a case study among a list in a broad variety of fields (see Table 2). Each case study was a 4-8 page background document. Note that some of the Case Studies were selected to relate to existing 'Student Design Teams' at the University of Waterloo, in order to promote student participation in these teams during their academic tenure. The students conducted an information and literature search exercise, where the students were guided through search of a wide variety of information systems and library databases to develop the following:

(1) Needs Analysis / Problem Statement

(2) Conceptual Design/Technology Options-introduce some of the current technological options to address the cases study (e.g. discuss a modern advance in the field, or current manufacturing process).

Students are recommended to identify at least three options.
(3) Criteria and constraints - identify some criteria and constraints that would be used in the detailed design to select between the proposed options.

(4) Design Tools and Processes - identify some design methodologies, or chemical engineering principles, or tools, or software, and/or processes that may be of use in the development of the detailed design.

The students were asked not to score the criteria, not to do costing and not actually evaluate the options with respect to the criteria.

In groups of 3 or 4 students (assigned randomly), 12 minute presentations were researched, prepared and presented to their peers and faculty over a two week period (with 12 tutorial hours, plus outside class time). Presentations were assessed for quality of presentation, depth of research, quality of research (and citation format), but most importantly the presentation of coherent Conceptual Design Concepts that related to the case study.

Table 2: Current conceptual case studies

- EcoCAR: The NeXt Challenge, design out an alternative fuel power train.

- Best Film Preparation Method For Dye Sensitized Solar Cells

- Applying Inherent Safer Design In An Existing Bromine Facility

- Oil Sand Consolidated Tailing Water Remediation

- H2U - Hydrogen Student Design Contest for a Residential Hydrogen Refueling System

- Volatile Organic Compound Abatement System

- Mission 2050 - Advanced Energy System At An Agricultural Operation

- Salt Reduction In Processed Food

- Separation Process For Dialysis

- Cereal Production

\section{RESULTS}

The engineering design methodology (Step 1) and the structured design assignment (Step 2) have been ongoing for a number of years and shown to be successful. The Conceptual Design Case Study assignment (Step 3) was implemented during the Fall 2010 term to the first year chemical engineering class, 134 students, divided in groups of 3-4 students. The learning objectives were assessed from a combination of written documents and one oral presentation. The quality of the work and the participation of the students were excellent and beyond our expectations, with student spending on average 18 hours of preparation time. Most students demonstrated an appropriate level of the following:

- Knowledge and consideration of relevant background material and issues;

- Clear, concise presentation and ability to respond to questions; and,

- Appropriate number, scope, breath, and quality of references.

Difficulties experienced by the students were related to:

- Distinction between criteria and constraints;

- Understanding of conceptual design and potential design tools; and,

- Working within a team format (although this was also identified as one of the more rewarding components of the exercise); and,

- Limit their work to proposed options.

\section{DISCUSSION}

The department will continue to offer the three steps components in the upcoming years. Ways to deal with students not participating in the group work remain to be developed. There will be expansion of this initial introduction to conceptual design to courses in upper years and fill the gap between this introduction to design and the last year capstone design project. The sustainability of this type of assignment will be the update of the case studies with changing chemical engineering needs.

\section{ACKNOWLEDGEMENTS}

We thank Amrita Yasin and Steve Lambert from the NSERC Waterloo Chair in Design (design.uwaterloo.ca) for their assistance with the design case studies and Anne Fullerton, Chemical Engineering Librarian Liaison at University of Waterloo. 